Real Knowing 



\title{
REAL KNOWING
}

New Versions of

the Coherence Theory

\author{
Linda Martín Alcoff
}

Cornell University Press

ITHACA AND LONDON 
An earlier, shorter version of chapters 4 and 5 appeared under the title "Foucault as Epistemologist" in Philosophical Forum 25, no. 2 (Winter 1993): 95-124.

\section{Copyright ( 1996 by Cornell University}

All rights reserved. Except for brief quotations in a review, this book, or parts thereof, must not be reproduced in any form without permission in writing from the publisher. For information, address Cornell University Press, Sage House, 512 East State Street, Ithaca, New York 14850.

First published 1996 by Cornell University Press.

First printing, Cornell Paperbacks, 2008

Printed in the United States of America

(6) The paper in this book meets the minimum requirements of the American National Standard for Information Sciences-

Permanence of Paper for Printed Library Materials, ANSI Z39.48-1984.

\section{Library of Congress Cataloging-in-Publication Data}

Alcoff, Linda.

Real knowing : new versions of the coherence theory / Linda Martín Alcoff. p. $\mathrm{cm}$.

Includes bibliographical references and index.

ISBN: 978-0-8014-7481-1

1. Knowledge, Theory of. 2. Truth-Coherence theory. I. Title. BD161.A43 1996 
For my mother, Laura, who bad children instead,

and for Larry,

who belped me have children anyway 
I think Mordecai Rich has about as much heart as a dirt-eating toad. Even when he makes me laugh I know that nobody ought to look on other people's confusion with that cold an eye.

"But that's what I am," he says, flipping through his scribble pad. "A cold eye. An eye looking for Beauty. An eye looking for Truth."

"Why don't you look for other things?" I want to know. "Like neither Truth nor Beauty, but places in people's lives where things have just slipped a good bit off the track."

"That's too vague," said Mordecai, frowning.

"So is Truth," I said. "Not to mention Beauty."

-Alice Walker, In Love and Trouble 